\title{
New evidence concerning the original relationships of early Precambrian volcanics and anorthosites in the Fiskenæsset region, southern West Greenland
}

\section{Jan C. Escher and John S. Myers}

With detailed mapping of the Fiskenæsset region nearing completion, the authors started coordination and synthesis of the geology of the region as a whole, in the field, during the summer.

The main lithologies of the region are quartzo-feldspathic gneisses, gneissose granites, amphibolites and anorthosite, with minor amounts of ultramafic rocks and metasediments. Their relationships, composition and structure have been summarised by Kalsbeek \& Myers (1973). Most of the quartzo-feldspathic gneisses appear to be derived from acid and intermediate intrusions into the older amphibolite and anorthosite units (Myers, in press). These gneisses were themselves deformed and then cut by thick sheets of porphyritic granite, Ilivertalik granite, in the north of the region.

Major new evidence was found concerning the character and relative age relationships of the oldest known rock units of the region:

(1) Evidence that many of the amphibolite units are derived from metavolcanics was found to be more widespread than had been recognised previously (fig. 12).

(2) Intrusive relationships were seen between the layered anorthosite complex and the metavolcanic amphibolites.

(3) Major units of metatonalite-diorite occurring in the southern part of the region were found to have intruded amphibolite units and themselves to have been intruded by acid and intermediate rocks, which form the main quartzo-feldspathic gneisses of the region.

\section{Metavolcanics}

Where remnants of primary structures are preserved, the amphibolite units are mostly seen to be derived from pillow lava, pillow lava breccia, dykes and sills. These are well preserved on a nunatak at the edge of the Inland Ice, east of Sermilik (J. C. E.), where pillow lava is interbedded with a few fine grained grey layers up to $80 \mathrm{~m}$ thick which are of quartz diorite composition (fig. 12). The least deformed pillow lavas contain relict vesicles, and the asymmetric shape of the pillows indicates the original way-up of the sequence. Ultramafic sills with rhythmic igneous layering also occur within the pillow lava sequence and some pass laterally into ultramafic pillows. The pillow lavas are cut by a large number of thin, fine grained, grey dykes of intermediate composition. The dykes are irregular in thickness and in some cases interfinger with individual pillows (fig. 13). This relationship probably indicates that these dykes were intruded soon after eruption of the pillow lavas, and before the lava pile had consolidated. Similar dykes are abundant in the southern part of the Fiskenæsset region, wherever pillow lava structures are well preserved, and they have been called Sarqarigsup nunâ dykes by Friend (in press) in the Ravns Stor $\varnothing$ area.

The pillow lavas generally consist of a fine grained leucocratic amphibolite with a 


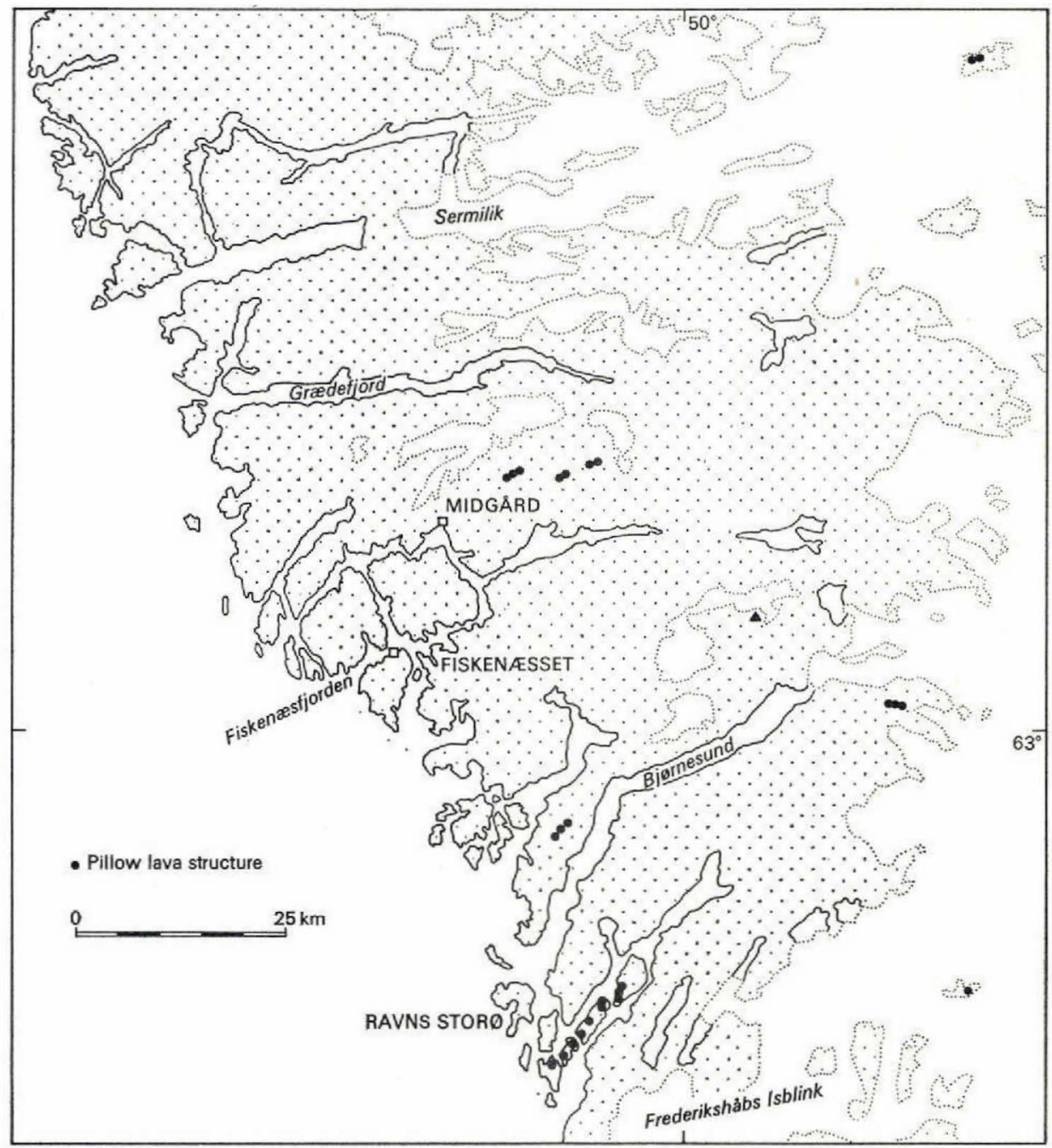

Fig. 12. Map of the Fiskenæsset region showing the location of GGU's base camp at Midgård and localities where pillow lava structures are preserved in amphibolite units. The solid triangle locates the well preserved roof contact of the anorthosite complex shown schematically in fig. 14 .

thin rim of melanocratic, finer grained amphibolite, probably derived from original chilled margins, in a matrix of melanocratic amphibolite. With increasing deformation and recrystallisation the melanocratic rims become indistinguishable from the matrix. Epidote, garnet, and scapolite have grown in the leucocratic amphibolite cores in many cases, and accentuate the apparent difference between pillow cores, rims and matrix.

There were primary variations in the packing density of lava pillows from layers of almost only pillows to layers with pillows scattered in a fine grained, probably tuffaceous 


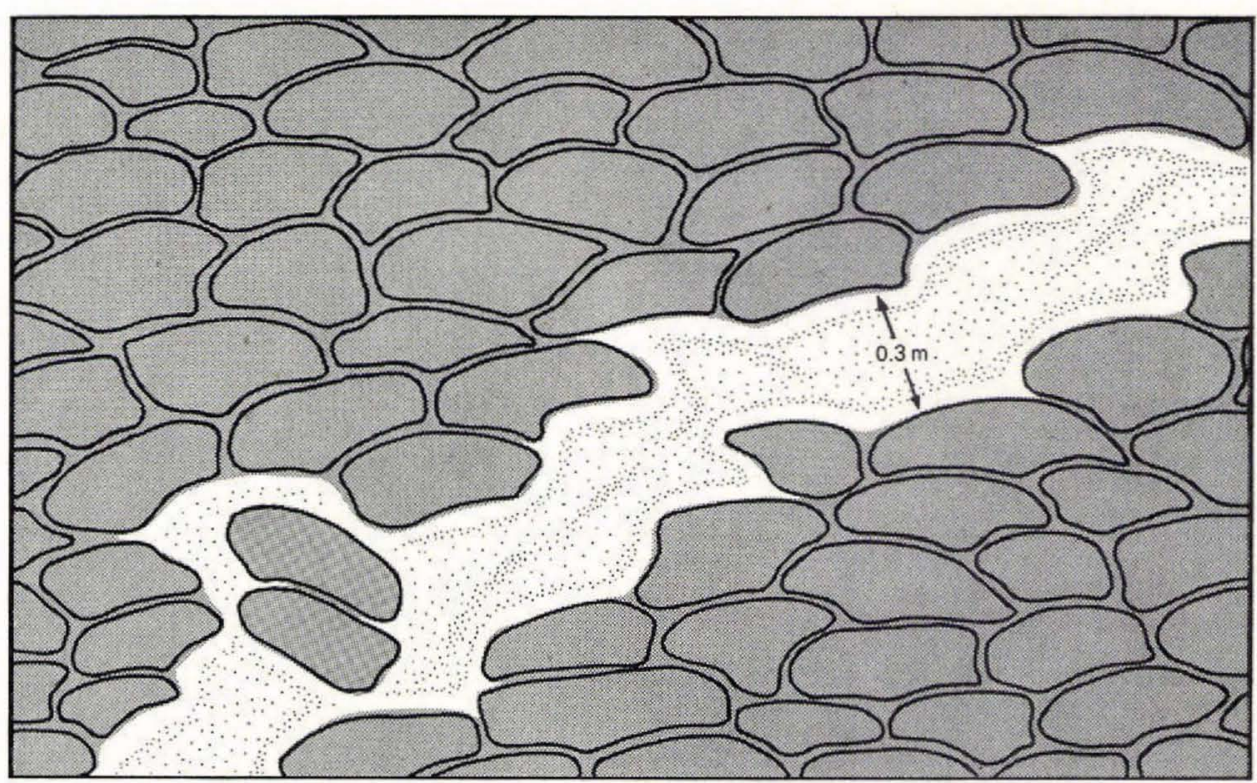

Fig. 13. Dyke of intermediate composition interfingering with basic pillow lava. Nunatak east of Sermilik, fig. 12.

or pillow breccia matrix. Pillow lava breccias were also seen to be interbedded with pillow lavas wherever pillow lava structures were well preserved. The breccias consist of jumbled, small angular or partly rounded fragments of leucocratic amphibolite with a variety of shapes and sizes, some with remnants of fractured, darker, finer grained margins, set in a fine grained melanocratic amphibolite matrix.

In most places where pillow lava, pillow lava breccia structures and grey dykes are preserved, they are cut by melanocratic amphibolite dykes. Many of these dykes contain large phenocrysts and relict phenocrysts of plagioclase, scattered irregularly throughout the dykes or concentrated near one margin. In the Ravns Stor $\varnothing$ amphibolite belt, these melanocratic amphibolite dykes also cut, and occur as sills within, a layered amphiboliteanorthosite unit, described by Andersen (1974). This amphibolite-anorthosite unit is different in appearance from the larger Fiskenæsset anorthosite complex and appears to be more closely associated with the amphibolite units. However, melanocratic amphibolite dykes, which may be related to those cutting this smaller layered amphiboliteanorthosite unit and the metavolcanic amphibolites, also cut the Fiskenæsset anorthosite complex.

\section{Intrusive relationships}

Clear igneous intrusive relationships were found between the anorthosite and amphibolite units for the first time (J.S.M.). Although it has previously been assumed that the anorthosite complex intruded the amphibolites (Kalsbeek \& Myers, 1973; Windley et al., 1973) this is the first clear proof of this relationship, except for chemical 

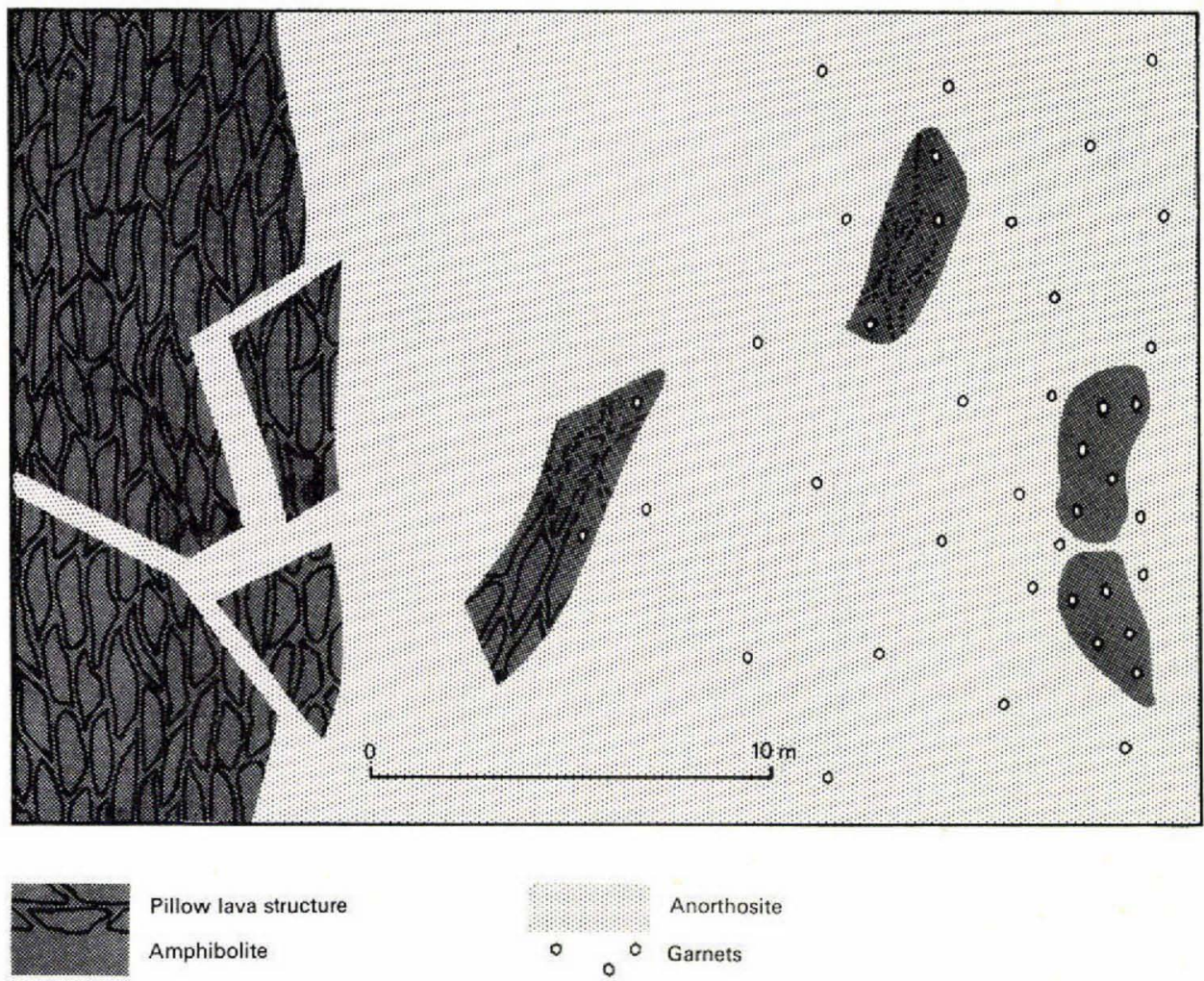

Pillow lava structure Amphibolite

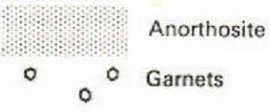

Fig. 14. Schematic illustration of the roof contact (to the left) of the Fiskenæsset anorthosite complex showing stoping of amphibolite with relict pillow lava structure. Individual pillows are not to scale. Location on fig. 12.

evidence, considered to indicate local contamination of anorthosite by host rocks (Herd, 1973) and rafts of amphibolite which were reported locally in the upper part of the anorthosite also by Herd.

At a roof contact of the anorthosite complex, the adjacent amphibolite contains remnants of pillow lava structure (fig. 14). It is locally veined by anorthosite and small blocks with relict pillow lava structure were stoped into the top of the anorthosite complex. In blocks more than $5 \mathrm{~m}$ below this roof contact, the pillow lava structures are less distinct and the small blocks are coarse grained melanocratic amphibolite with large garnet porphyroblasts. Garnet, which is absent from the top $5-10 \mathrm{~m}$ of the anorthosite, is abundant at and below this level where the amphibolite blocks are more coarsely recrystallised. The increasing recrystallisation of the amphibolite blocks with distance from the roof contact appears to have been accompanied by increasing contamination of the anorthosite.

Where the top of the layered anorthosite complex is in contact with ultramafic layers within the amphibolite sequence, a generally 2-20 m wide zone of marked chemical reaction and coarse recrystallisation occurs. These contact zones contain a variety of 
exotic minerals such as sapphirine and kornerupine, together with phlogopite, gedrite, enstatite, corundum, rutile and molybdenite. These minerals are the results of both contact metamorphism-metasomatism of the anorthosite complex, and subsequent regional metamorphisms, and have been described in detail by Herd et al. (1969), and by Herd $(1972,1973)$. Primary contact relationships are blurred in these contact zones but in a few places thin veins and sills of anorthosite were seen within the ultramafic rocks. These veins may preserve original intrusive relationships. In the Majorqap qâva anorthosite outcrop (Myers, 1973), veins of anorthosite cut across the underlying gabbros and leucogabbros after they had been strongly deformed. Consequently, anorthosite veins which cut ultramafic roof rocks may either date from the original intrusion of the leucogabbro-anorthosite sheet, or from subsequent tectonic events which may have occurred either before or after consolidation of the uppermost anorthosite unit.

\section{References}

Andersen, L. S. 1974: Rapport over geologien mellem Frederikshåbs Isblink og Quvnilik fjord - Vest Grønland. Unpublished thesis, Univ. of Copenhagen. 295 pp.

Friend, C. R. L. in press: A metamorphosed basic dyke swarm in the vicinity of Sarqarigsup nunâ (Ravns Stor $\varnothing$ area), Fiskenæsset, southern West Greenland. Rapp. Grønlands geol. Unders.

Herd, R. K. 1972: The petrology of the sapphirine-bearing and associated rocks of the Fiskenæsset complex, West Greenland. Unpublished Ph. D. thesis, Univ. of London, $606 \mathrm{pp}$.

Herd, R. K. 1973: Sapphirine and kornerupine occurrences within the Fiskenæsset complex. Rapp. Grфnlands geol. Unders. 51, 65-71.

Herd, R. K., Windley, B. F. \& Ghisler, M. 1969: The mode of occurrence and petrogenesis of the sapphirine-bearing and associated rocks of West Greenland. Rapp. Grønlands geol. Unders. 24, $44 \mathrm{pp}$.

Kalsbeek, F. \& Myers, J. S. 1973: The geology of the Fiskenæsset region. Rapp. Gronlands geol. Unders. 51, 5-18.

Myers, J. S. 1973: Igneous structures and textures in the Majorqap qâva outcrop of the Fiskenæsset anorthosite complex. Rapp. Grønlands geol. Unders. 51, 47-53.

Myers, J. S. in press: Acid and intermediate intrusions, deformation and gneiss formation, north-east of Fiskenæsset. Rapp. Gronlands geol. Unders

Windley, B. F., Herd, R. K. \& Bowden, A. A. 1973: The Fiskenæsset complex, West Greenland. Part I. A preliminary study of the stratigraphy, petrology, and whole-rock chemistry from Qeqertarssuatsiaq. Bull. Grønlands geol. Unders. 106 (also Meddr Grønland 196,2) $80 \mathrm{pp}$. 